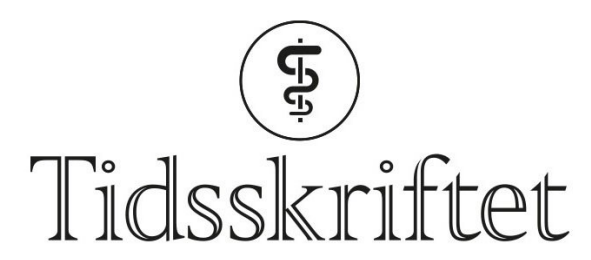

DEN NORSKE LEGEFORENING

\title{
Muitosátni Ole Mathis Hetta
}

MINNEORD

ÁNNE LÁJLA WESTERFJELL KALSTAD

SIV KVERNMO

ÁNNE LÁILÁ NYSTAD

MÁRET LÁJLÁ NEDREJORD

FRØYDIS NYSTAD NILSEN

MAY BRITT NYSTAD

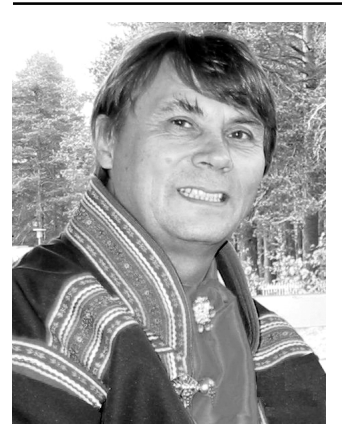

Ole Mathis Hetta/Siebe-Ole Máhtte riegádii Guovdageainnus 1946. Son gárvii artiuma Nordfjordeid riikagymnásas 1965, ja dan mạnil gárttai son okta dain vuosttaš sámi doavttirstudeanttain universitehtas Bergenis.

Doppe son válddii medisiinnalaš ámmáteksámena 1971. Sus lei turnusbargu Rogalándda buohcciviesus ja Bryne suohkanis.

Mạnil militearabálvalusa Vatneleiren báikkis Sandnes guovllus máhcai son SisFinnmárkui ja lei guovlludoavttir Kárášjogas njeallje jagi (1974-78). Ole Máhtte čájehii beroštumi iešguđetge kultuvrraide ja álbmogiidda geat rahče oččodit dearvvašvuođabálvalusaid. Danin son álggii bargat Girku heahteveahki ovddas. Son barggai mángga dearvvašvuođaprošeavttain Mátta-Sudanas ja Tanzanias. Dáid vásáhusaid geažil sihke Sámis ja Afrihkás almmuhii son iežas vásáhusaid ja árvvoštallamiid das makkár mearkkašupmi olbmo kultuvra duogážis lea go galgá áddet dearvvašvuođa ja buozalmasvuođa.

1983-84 studerii son Berkeley Universitehtas Californias. Doppe son válddii mastergráda servvodatmedisiinnas (Master of Public Health). Go sámi doaktáriidsearvi ásahuvvui 1984 
de lei Ole Máhtte barggus Afrihkás. Dan geažil sus ii lean vejolašvuohta searválaga eará sámi bargoustibiiguin buoredit sápmelaččaid dearvvašvuođabálvalusaid. Go son de fas máhcai Stavangerii 1986, de gal oaččui searvi buori veahki su vásáhusaid, bastilis reflekšuvnnaid ja cealkámušaid bokte. Ja dasa lassin lassánii su ángiruššan dáđi eanet áiggi mielde.

Su servvodatmedisiinnalaš čehppodaga ja barggu dihte lei son háhkan alcces nana hárjáneami dan bokte go lei sihke leamašan fylkkadoavttir Rogalánddas, jođiheaddji almmolaš doaktáriid searvvis ja seniorráđđeaddi sámi servvodatmedisiinnas Dearvvašvuođadirektoráhtas 2007-13. Dá ledje vásáhusat mat bohte ávkin go šattai sámi doaktáriid searvvi jođiheaddji 2014. Son ángirušai garrasit bargui ásahit Sámi dearvvašvuođasiidda Kárášjohkii ja oččodit sámi doaktáriid bargagoahtit sámi dearvvašvuođaguovddážiin. Sus lei maid internašunála beroštupmi álgoálbmotdearvvašvuođa fáttáide.

Ole Máhtte oaččui olu gudni ja fuomášumi iežas barggu ja ángiruššama dihte. 2013 oaččui son Karl Evang bálkkašumi iežas barggu dihte sámi pasieanttaid ovddas. 2015 oaččui son Fyrbøterbálkkašumi Norgga doaktáriidsearvvis ja 2016 geigejuvvui sutnje St. Olavs Árvomearkka 1. Luohká Riddár su erenoamáš barggu ovddas buoredit álgoálbmot vuoigatvuođaid ja dearvvašvuođa dili.

Son šattai penšunista seamma jagi go válljejuvvui sámi doaktáriid searvvi jođiheaddjin 2014. Váikko son buozai de doaimmahii iežas jođiheaddjiámmáha hui bures ja ii diktán goassige dávdda stivret.

Son lei dego nana bákti ja doarjja sihke nuorabuš ja boarrásut bargoustibiidda. Sus lei mearehis dáhttu ovddidit sámi dearvvašvuođa ja bidjat dan beaiveortnegii. Son hástalii sihke dearvvašvuođabyrokráhtaid ja politihkkáriid buoredit dearvvašvuođabálvalusaid sápmelaččaide.

Ole Máhtte vádjolii geassemánu 8 b. 2017 mạnil guhkit áigge buozalmasvuođa. Mii gal váillahišgoahtit su ángiruššama ja ángirvuođa. Min jurdagat mannet bearrašii. Ráfi lehkos su muitui.

Sámi doaktáriidsearvvi stivrramiellahtut

\section{Ole Mathis Hetta}

Ole Mathis Hetta var født i Kautokeino i 1946. Etter å ha tatt artium ved Nordfjordeid landsgymnas i 1965 ble han en av de første samiske medisinstudentene ved Universitetet i Bergen, hvor han tok sin medisinske embetseksamen i 1971. Han hadde turnustjeneste ved Rogaland sykehus og i Bryne kommune.

Etter militærtjenesten ved Vatneleiren i Sandnes dro han tilbake til Indre Finnmark og ble distriktslege i Karasjok i fire år (1974-78). Hans interesse for ulike kulturer og grupper som kjempet for å få en tilgjengelig helsetjeneste, førte ham til Kirkens Nødhjelp og til flere helseprosjekter i Sør-Sudan og Tanzania. I lys av sin innsikt fra både Sápmi og Afrika publiserte han sine erfaringer og betraktninger om betydningen av menneskets kulturelle bakgrunn for forståelsen av helse og sykdom.

I 1983-84 studerte han ved Berkeley University i California hvor han tok en mastergrad i samfunnsmedisin (Master of Public Health). Da Samisk legeforening ble etablert i 1984, var Ole Mathis i tjeneste i Afrika. Han ble derfor ikke med i oppstarten av samiske kollegers arbeid for en bedre helsetjeneste for den samiske befolkningen. Senere, da han kom tilbake til Stavanger i 1986, fikk foreningen gleden av hans erfaringer, skarpe refleksjoner og replikker, og ikke minst hans engasjement som bare vokste seg sterkere og sterkere med årene. Hans samfunnsmedisinske kunnskap og engasjement gjennom erfaringer som fylkeslege i Rogaland, leder av offentlige legers forening og som seniorrådgiver i samisk samfunnsmedisin i Helsedirektoratet 2007-13, kom godt med da han i 2014 ble leder i Samisk legeforening. Med liv og glød engasjerte han seg i arbeidet med opprettelsen av Samisk helsepark i Karasjok og i rekrutteringen av samiske leger til samisk helsetjeneste. 
Han hadde også et internasjonalt engasjement for urfolks helse.

Ole Mathis mottok mye heder og ære for sitt arbeid og engasjement. I 2013 mottok han Karl Evangs pris for sitt arbeid for den samiske pasienten. Han fikk fyrbøterprisen i 2015 fra Den norske legeforening, og i 2016 ble han utnevnt til St. Olavs ridder av 1. klasse for sin pionerinnsats for urfolks rettigheter og helse.

I 2014 ble han pensjonist og samme år leder for Samisk legeforening. Selv om han ble syk, sto han på i sitt verv som leder og lot aldri sykdommen ta føringen. Han var en bauta og en støtte så vel for yngre som eldre kolleger. Han hadde en ukuelig vilje til å sette samisk helse på dagsorden. Han utfordret så vel helsebyråkrater som politikere for å bedre helsetjenesten for den samiske befolkningen.

Ole Mathis gikk bort 8. juni 2017 etter lang tids sykdom. Vi vil savne hans engasjement og pågangsmot. Våre tanker går til hans familie, og vi lyser fred over hans minne.

Styret for Samisk legeforening

Publisert: 28. november 2017. Tidsskr Nor Legeforen. DOI: 10.4045/tidsskr.17.0543

(C) Tidsskrift for Den norske legeforening 2020. Lastet ned fra tidsskriftet.no 